\title{
Evaluation of acetone cyanohydrin effect in "in vitro" inativation of the Ehrlich ascites tumor cells ${ }^{1}$
}

\author{
Avaliação do efeito de acetona cianidrina na inativação de células do tumor ascítico de Ehrlich \\ "in vitro"
}

\author{
Rondon Tosta Ramalho', Ricardo Dutra Aydos" Marney Pascoli Cereda ${ }^{\mathrm{III}}$ \\ ${ }^{\mathrm{I}}$ Fellow PhD degree, Health and Development Postgraduation, Federal University of Mato Grosso do Sul (UFMS) and Master in Biotechnology, \\ UCDB, Campo Grande-MS, Brazil. \\ II PhD, Associate Professor, Department of Surgery, UFMS, Campo Grande-MS, Brazil.

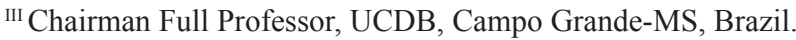

\begin{abstract}
Purpose: To evaluate the antitumor effect of acetone cyanohydrin in Ehrlich ascites tumor cells in vitro. Methods: The Ehrlich ascites tumor cells and lymphocytes were incubated with different concentrations of acetone cyanohydrin $(0,0.5,1.0,2.0,10.0,20.0$ and $30.0 \mu \mathrm{g} \cdot \mathrm{mL}^{-1}$ ), After 1, 2, 3, 4, 18 and 24 hours cell viability tests were performed by the trypan blue method. Results: The results demonstrated a dose-dependent cytotoxic effect against the cells of Ehrlich ascites tumor. The concentrations of 20 and $30 \mu \mathrm{g} . \mathrm{mL}^{-1}$ was $100 \%$ of cell death in only 1 and 2 hours respectively. In lower doses of 0.5, 1.0 and $2.0 \mu \mathrm{g} . \mathrm{mL}^{-1}$ the cytotoxic effect was less

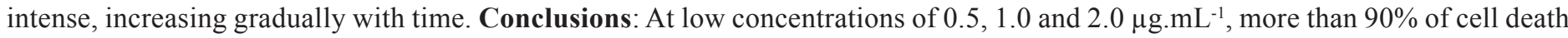
was observed only after 24 hours of incubation which is the evidence that the tumor cell has the ability to poison cumulatively and irreversibly itself with the acetone cyanohydrin when compared with the results presented by human lymphocytes that the same doses and at the same time of incubation reached a maximum of $30 \%$ of cell death, suggesting an activity of rhodanese differentiated between the two cells.
\end{abstract}

Key words: Carcinoma, Ehrlich Tumor. Acetone. Neoplasms. In vitro.

\section{RESUMO}

Objetivo: Avaliar o efeito antitumoral da acetona cinidrina em células do tumor ascítico de Ehrlich in vitro. Métodos: Células do tumor ascítico de Ehrlich e linfócitos foram incubadas com diferentes concentrações de acetona cianidrina (0, 0,5, 1,0, 2,0, 10,0, 20,0 e 30,0 $\mu \mathrm{g} . \mathrm{mL}^{-1}$ ), depois de $1,2,3,4,18$ e 24 horas foi verificada a viabilidade celular atravéz do método de azul de trypan. Resultados: Os resultados demonstraram um efeito citotóxico dose dependente frente as células do tumor ascítico de Ehrlich. Nas concentrações de 20 e $30 \mu \mathrm{g} . \mathrm{mL}^{-1}$ ocorreu $100 \%$ de morte celular em apenas 1 e 2 horas respectivamente. Nas doses mais baixas de $0,5,1,0$ e $2,0 \mu \mathrm{g} . \mathrm{mL}^{-1} \mathrm{o}$ efeito citotóxico foi menos intenso, aumentando gradativamente com o tempo. Conclusões: Nas concentrações baixas de 0,5 . 1,0 e 2,0 $\mu \mathrm{g} . \mathrm{mL}^{-1}$, foi observado mais de $90 \%$ de morte celular somente após 24 horas de incubação o que evidência a capacidade da célula tumoral de se intoxicar de maneira irreversível e acumulativa com a acetona cianidrina, quando comparadas com os resultados apresentados pelos linfócitos humanos que nas mesmas doses e nos mesmos tempos de incubação atingiram um máximo de $30 \%$ de morte celular, o que sugere uma atividade de rodanase diferenciada entre as duas células.

Descritores: Carcinoma de Ehrlich. Acetona. Neoplasias. In vitro.

${ }^{1}$ Research performed at the Postgraduate Program in Biotechnology, Dom Bosco Catholic University (UCDB), Campo Grande, Brazil. 


\section{Introduction}

The cyanide is a common substance in the environment and both men and animals can be exposed to it through different means including water, and acrylic plastics, cigarette smoke and cyanogen plants. These are important sources of cyanide in the form of cyanogen glycosides practically stable in environmental conditions. From these, the Linamarin and Lotaustralin are known to be present in cassava, a species of Manihot $s p^{1}$.

The Acetone Cyanohydrin is also known as 2 - methyl Lactonitrile or $\alpha$ - Hydroxisobutironitrile. It is an aqueous liquid, colorless, with mild odor of almonds and miscible in water. It is used commercially in the manufacture of acrylic (poly methyl methacrylate $)^{2}$. Acetone Cyanohydrin has the molecular mass of 85.11 , density 0.925 to $25{ }^{\circ} \mathrm{C}$ and melting point of $-19{ }^{\circ} \mathrm{C}$. It is capable of spontaneous release of cyanide depending only on the $\mathrm{pH}$.

As exposure to cyanide is inevitable due to natural cyanogen compounds, many organisms have developed pathways that allow them to make the detoxification of this compound. However, when the amount of cyanide is superior to that which natural detoxification mechanisms are able to eliminate, the possibility of cyanide poisoning is considered. The cyanide, once absorbed, is distributed rapidly by red blood cells and the tissues. The detoxification occurs through the combination of cyanide with sulfur (S) to form thiocyanate. This combination can occur through reactions catalyzed by rhodanese. The thiocyanate, made less toxic, is eliminated via the kidney ${ }^{3,4}$. The detoxification occurs in all normal human cells but cancer cells, which have a low activity of rhodanese become vulnerable to the toxic effect of cyanide 5 .

Most current studies involving cyanogenic substances concerns Linamarin or Amygdalin and they found no report of the use of Acetone Cyanohydrin as an antitumor. The purpose of the study was to evaluate the antitumor effect of Acetone Cyanohydrin in Ehrlich Ascites Tumor cells in vitro.

\section{Methods}

\section{Treatment}

It has been used as a source acetone cyanohydrin Sigma-Aldrich with $99 \%$ purity.

\section{Donor animals}

We used male Swiss mice weighing 20-30g, inoculated with the Ehrlich Ascites Tumor (EAT) obtained from animals carrying the same tumor, donated by Dr. Denise Fecchio researcher of the Department of Pathology, Faculty of Medicine, UNESP, Botucatu, SP, Brazil. The mice were maintained and multiplied in the biothery of the Dom Bosco Catholic University (DBCU), Campo Grande, MS, Brazil. All procedures were performed in accordance with the Research Ethics Committee of DBCU (Protocol No. 048/2008A).

\section{Neoplasia}

For obtaining and maintaining the tumor cells were followed the protocols of the Department of Pathology, Faculty of Medicine, UNESP, Botucatu were followed ${ }^{6}$. The mice were euthanized with excessive dose of inhaled anesthetics. After that, a peritoneal lavage with $3 \mathrm{~mL}$ of saline was conducted, and then it was removed by suction of the $3 \mathrm{~mL}$ saline. The cell suspension obtained was centrifuged, the supernatant was discarded and the pellet resuspended with $3 \mathrm{~mL}$ of saline. The suspension tested the viability of cell throught the exclusion of trypan blue. Then, it was determined the number of cells in Neubauer chamber.

\section{Collection of human lymphocytes}

The lymphocytes were obtained from human blood as approved by the Ethics Committee in Research of DBCU. Blood was collected from healthy volunteers aged between 18 and 40 years, who were not making use of drugs, tobacco and alcohol. The blood was collected from the antecubital vein between 7:00 and 10:00 in the morning in heparinized tubes and sterile conditions.

\section{Isolation of lymphocytes}

The blood collected was mixed by inversion. Blood $(7 \mathrm{~mL})$ was slowly placed in a centrifuge tube containing $3 \mathrm{~mL}$ of Ficoll-PaqueTM Plus and centrifuged for $30 \mathrm{~min}$. to $1000 \mathrm{~g}$. Then the lymphocyte cloud was taken with Pasteur pipette and washed 3 times with the medium culture Dulbecco's Modified Eagle's (DMEM) not supplemented. Then, the lymphocytes were used for cell culture ${ }^{7}$.

\section{Experimental design}

\section{$\underline{\text { Cells preparation and culture }}$}

The suspension obtained from the EAT and lymphocytes after being washed were resuspended in medium Dulbecco's Modified Eagle's (DMEM) supplemented with 5\% fetal bovine serum and the suspension adjusted to $1.0 \times 10^{5}$ cells. $\mathrm{mL}^{-1}$.

After adjusting the concentration of $1.0 \times 10^{5}$ cells EAT the suspensions and the lymphocytes were separated into aliquots of $1.0 \mathrm{~mL}$ and cultured with 0 (control), $0.5,1.0,2.0,10.0$, 20.0 and $30.0 \mu \mathrm{g}$ of Acetone Cyanohydrin in DMEM supplemented with $5 \%$ fetal serum, with a $\mathrm{pH}$ between 7.0 and 7.2. After 1, 2, 3, 4, 18 and 24 hours cell viability tests were performed, and this procedure was repeated twice in duplicate.

\section{Determination of cell viability}

\section{Test of exclusion of trypan blue}

Cell viability was assessed using the Test of Exclusion of trypan blue, which is based on a test of membrane integrity. We used a 1:2 dilution of the culture of cells in the trypan blue and then the counting of the cells made in a Neubauer hemocytometer being considered live cells (viable) the ones which exclude the trypan blue and dead cells (not viable) the ones which incorporate the dye. The result was expressed in percentage.

\section{Statistical analysis}

The results were analyzed by ANOVA with two variables. When the differences between the average were significant Bonferroni's test was applied. The significance level was 5\% $(\mathrm{p}<0.05)$. 


\section{Results}

The results showed cytotoxic effect for tumor cells in all concentrations of Acetone Cyanohydrin. It was also found dose-dependent effect, ie the higher the dose tested the highest cytotoxic effect on these cells (Figure 1). In human lymphocytes less intense cytotoxic effect was observed, but also with dosedependent effect.

In 20 and $30 \mu \mathrm{g} \cdot \mathrm{mL}^{-1}$ concentrations was found the most intense cytotoxic effect leading to death of $100 \%$ of cells. In lower doses of $0.5,1.0$ and $2.0 \mu \mathrm{g} . \mathrm{mL}^{-1}$ the cytotoxic effect was less intense, increasing gradually with time (Figure 1). In human lymphocytes, there was more moderate cytotoxic effect. At the doses $0.5,1.0$ and $2.0 \mathrm{mg} . \mathrm{mL}^{-1}$ it was recorded the highest mortality rate in the dosage of $2.0 \mu \mathrm{g} \cdot \mathrm{mL}^{-1}$ after $24 \mathrm{~h}$ of incubation, which was the order of $30 \%$ and did not reach $25 \%$ to the dose of 0.5 and $1.0 \mu \mathrm{g} . \mathrm{mL}^{-1}$.
It was observed that the results showed significant differences among the doses used and in time of incubation $(p<0.05)$. The results showed that the interactions between concentrations and incubation time are extremely significant $(p<0.0001)$ and also has a very significant effect on results $(p<0.0001)$, the same happened with the concentrations of Acetone Cyanohydrin $(\mathrm{p}<0.0001)$.

There was no significant difference in the results obtained in concentrations of 0.5 and $10 \mu \mathrm{g} . \mathrm{mL}^{-1}$ Acetone Cyanohydrin when comparing the time of incubation of 1 and 2 hours for human lymphocytes $(\mathrm{p}>0.05)$. There was also no significant difference between the incubation period of 1 and 3 hours for human lymphocytes at concentrations of 2.0 and $10 \mu \mathrm{g} \cdot \mathrm{mL}^{-1}(\mathrm{p}>0.05)$, as showed in Figure 1, Tables 1 and 2.

TABLE 1 - Effect of treatment with acetone cyanohydrin on the cells of Ehrlich ascites tumor in vitro

Percentage of dead cells $(\%) *$

\section{Concentration in $\mu \mathrm{g} \cdot \mathrm{mL}^{-1}$}

\begin{tabular}{|c|c|c|c|c|c|c|c|}
\hline Hours & Control & 0.5 & 1.0 & 2.0 & 10 & 20 & 30 \\
\hline 1 & $9.4 \pm 5.5$ & $11.6 \pm 0.0 * *$ & $11.6 \pm 0.7 * *$ & $7.3 \pm 0.3 * *$ & $24.3 \pm 0.1 * * *$ & $76.0 \pm 0.6 * * *$ & $92 \pm 1.6 * * *$ \\
\hline 2 & $8.0 \pm 2.8$ & $18.9 \pm 3.4 * * *$ & $12.9 \pm 0.8 * *$ & $10.6 \pm 0.4 * *$ & $31.8 \pm 4.9 * * *$ & $84.9 \pm 6.8 * * *$ & $100.0 * * *$ \\
\hline 3 & $9.5 \pm 2.5$ & $13.7 \pm 0.1 * *$ & $23.8 \pm 3.8 * * *$ & $16.1 \pm 3.8 * * * *$ & $65.8 \pm 1.0 * * *$ & $100.0 * * *$ & $100.0 * * *$ \\
\hline 4 & $10.7 \pm 0.8$ & $13.5 \pm 4.1 * *$ & $17.9 \pm 0.1 * * * *$ & $12.8 \pm 0.8 * *$ & $87.3 \pm 2.7 * * *$ & $100.0 * * *$ & $100.0 * * *$ \\
\hline 18 & $12.5 \pm 1.4$ & $62.5 \pm 0.1 * * *$ & $82.6 \pm 0.3 * * *$ & $77.8 \pm 0.1 * * *$ & $100.0 * * *$ & $100.0 * * *$ & $100.0 * * *$ \\
\hline 24 & $25.4 \pm 1.6$ & $78.9 \pm 3.4 * * *$ & $90.9 \pm 1.3 * * *$ & $90.9 \pm 0.1 * * *$ & $100.0 * * *$ & $100.0 * * *$ & $100.0 * * *$ \\
\hline
\end{tabular}

Percentage of cell death (\%) after incubation of tumor cells $\left(10^{5}\right.$ cells. $\left.\mathrm{mL}^{-1}\right)$ with saline (control) and $0.5,1.0,2.0,10.0,20.0$ and 30.0 $\mu \mathrm{g} \cdot \mathrm{mL}^{-1}$ Acetone Cyanohydrin and cell viability assessed using the Test of Exclusion of trypan blue with two replications. ** $\mathrm{p}>0.05$, $* * * \mathrm{p}<0.001$ and $* * * * \mathrm{p}<0.05$, in relation to control. 
1-hour incubation

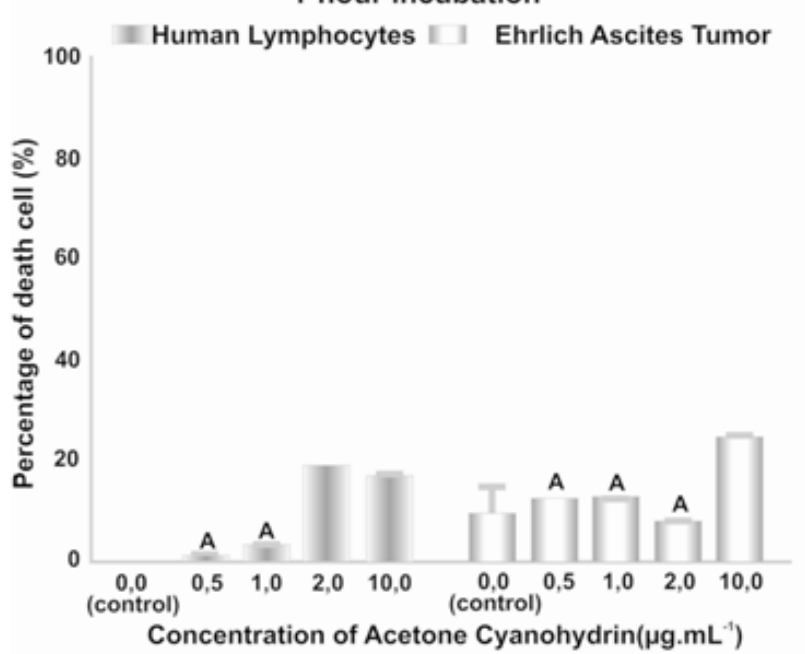

3-hour incubation

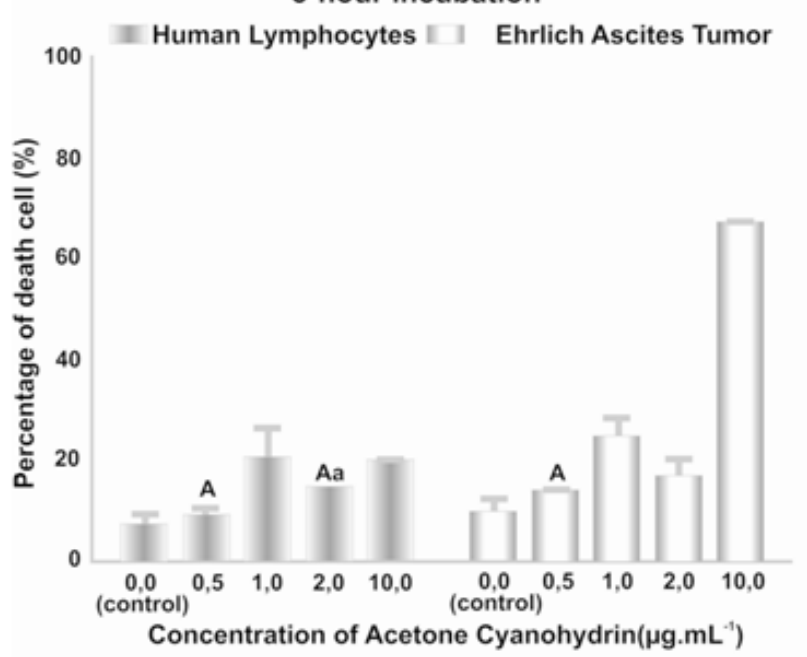

18-hour incubation

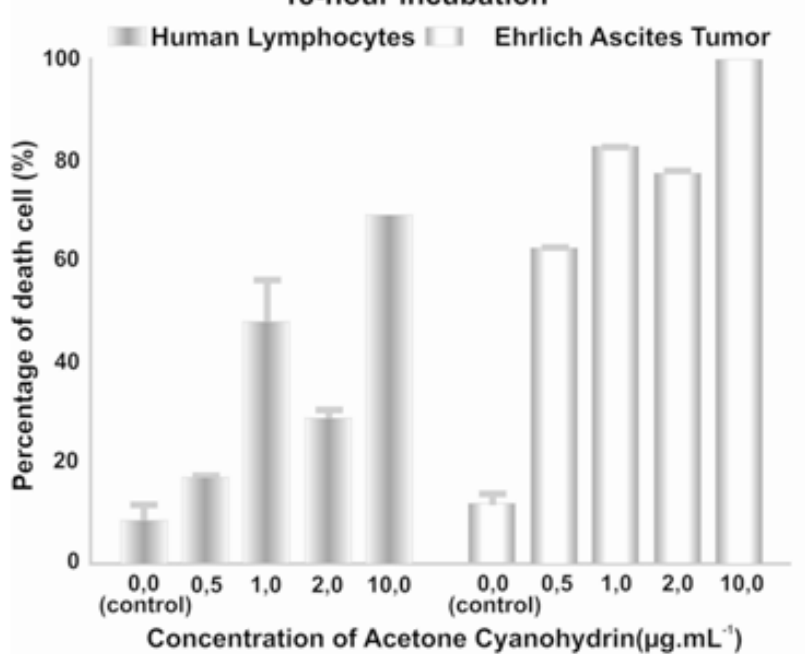

2-hour incubation

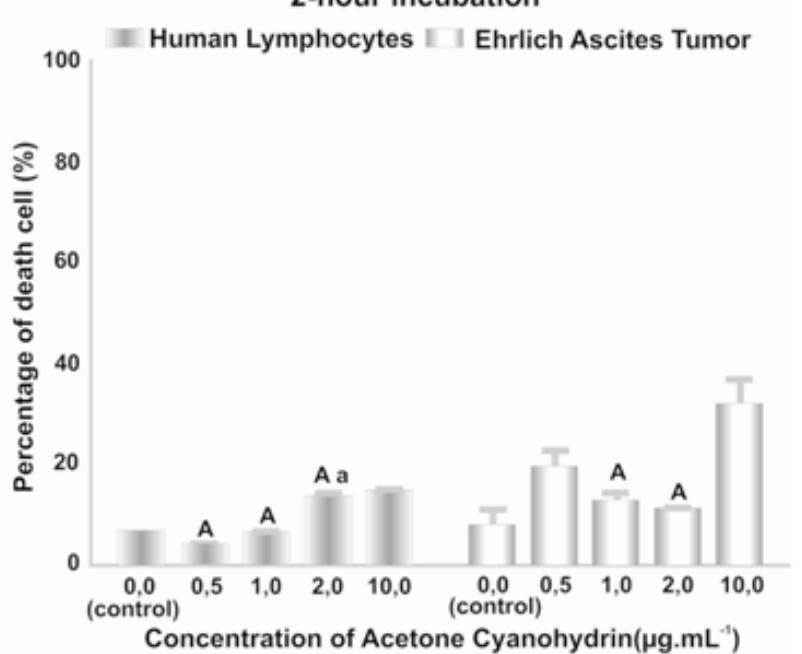

4-hour incubation

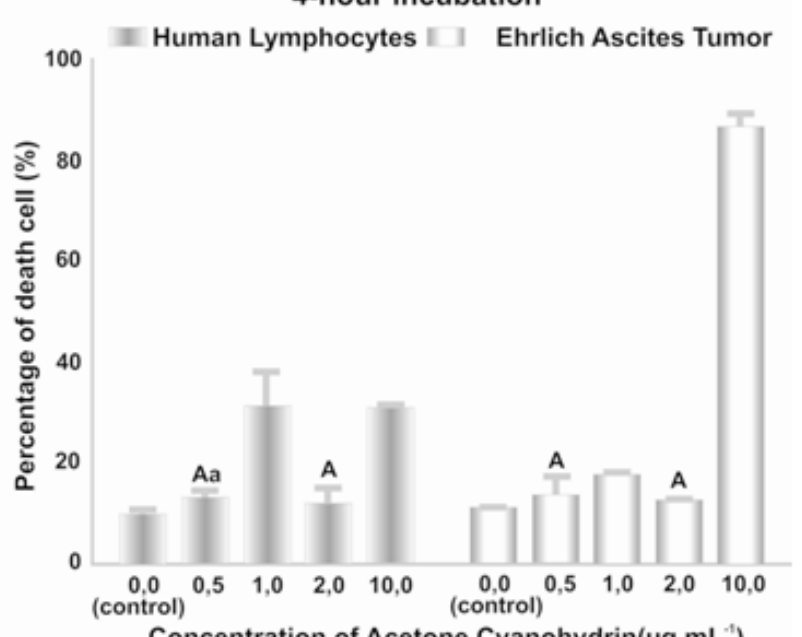

Concentration of Acetone Cyanohydrin $\left(\mu \mathrm{g} \cdot \mathrm{mL}^{-1}\right)$

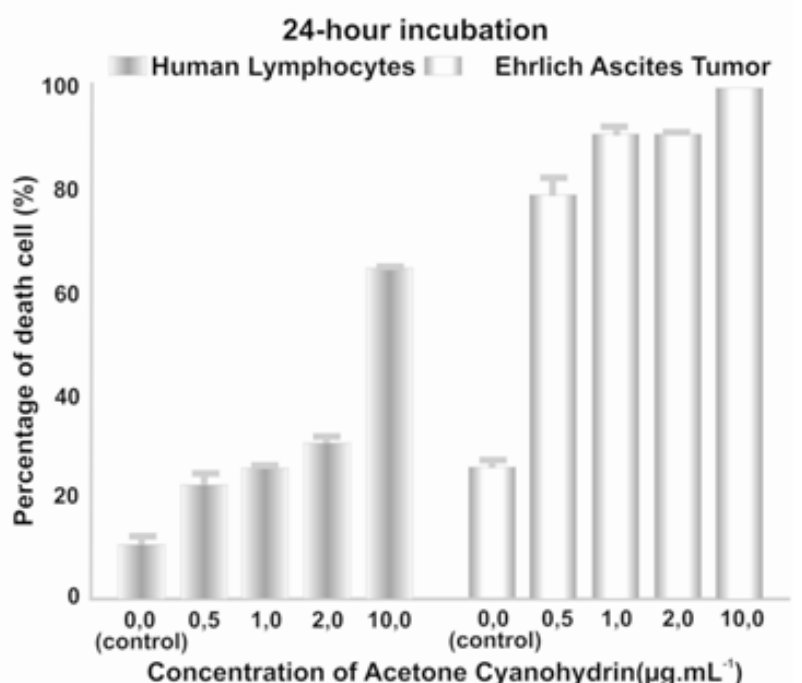

FIGURA 1 - Percentage of mortality of human lymphocytes and cells of the Ehrlich ascites tumor after incubation with acetone cyanohydrin. Results are the mean $\pm \mathrm{SD}$ for two independent experiments. A - present no significant difference in the control ( $\mathrm{p}>0.05$ ). a- present no significant difference when compared with cells of EAT ( $p>0.05)$ 
TABLE 2 - Effect of treatment with acetone cyanohydrin on hunamos lymphocytes in vitro

Percentage of dead cells $(\%)$ *

\section{Concentration in $\mu \mathrm{g} . \mathrm{mL}^{-1}$}

\begin{tabular}{cccccc}
\hline Hours & Control & $\mathbf{0 . 5}$ & $\mathbf{1 . 0}$ & $\mathbf{2 . 0}$ & $\mathbf{1 0}$ \\
\hline $\mathbf{1}$ & $0.0 \pm 0.0$ & $0.9 \pm 0.1^{* *}$ & $2.6 \pm 1.2^{* *}$ & $18.3 \pm 0.1^{* * * * *}$ & $17.1 \pm 0.7^{* * * * *}$ \\
\hline $\mathbf{2}$ & $6.0 \pm 0.1$ & $3.3 \pm 1.0^{* *}$ & $6.3 \pm 0.1^{* *}$ & $13.4 \pm 0.9^{* *}$ & $14.4 \pm 0.6^{* * *}$ \\
\hline $\mathbf{3}$ & $6.9 \pm 2.3$ & $8.7 \pm 1.6^{* *}$ & $19.7 \pm 6.5^{* * * * *}$ & $14.4 \pm 0.0^{* *}$ & $19.3 \pm 0.4^{* * * * *}$ \\
\hline $\mathbf{4}$ & $9.0 \pm 1.7$ & $13.2 \pm 1.3^{* *}$ & $30.8 \pm 7.4^{* * * * *}$ & $11.8 \pm 3.3^{* *}$ & $30.1 \pm 1.4^{* * * * *}$ \\
\hline $\mathbf{1 8}$ & $8.2 \pm 3.8$ & $17.0 \pm 0.6^{* * *}$ & $47.9 \pm 8.9^{* * * * *}$ & $28.8 \pm 2.0^{* * * * *}$ & $68.9 \pm 0.0^{* * * * *}$ \\
\hline $\mathbf{2 4}$ & $10.5 \pm 1.4$ & $22.0 \pm 2.3^{* * * *}$ & $24.6 \pm 1.0^{* * * * *}$ & $30.0 \pm 1.4^{* * * * *}$ & $64.6 \pm 0.2^{* * * * *}$
\end{tabular}

Percentage of cell death (\%) after incubation of human lymphocytes $\left(10^{5}\right.$ cells. $\left.\mathrm{mL}^{-1}\right)$ with saline (control) and 0.5 , 1.0, 2.0 and $10.0 \mu \mathrm{g} . \mathrm{mL}^{-1}$ of Acetone Cyanohydrin and cell viability assessed through the test of exclusion of trypan blue with two replications. ${ }^{* *} \mathrm{p}>0.05, * * * \mathrm{p}<0.05, * * * * \mathrm{p}<0.01$ and $* * * * * \mathrm{p}<0.001$, in relation to control.

When comparing the time of incubation of human lymphocytes with the time of incubation of EAT cells, significant differences were observed in almost all times and concentrations of Acetone Cyanohydrin $(\mathrm{p}<0.001)$. A significant difference was not detected at concentrations of $2.0 \mu \mathrm{g} \cdot \mathrm{mL}^{-1}$ of Acetone Cyanohydrin in 2 hours ( $>0.05)$ and 3 hours $(p>0.05)$ of incubation and at concentrations of $0.5 \mu \mathrm{g} \cdot \mathrm{mL}^{-1}$ Acetone Cyanohydrin and in 4 hours of incubation ( $p>0.05)$.

These results, as shown in Table 1 and Figure 1, showed the effect of Acetone Cyanohydrin causing death of tumor cells. It can be observed that at doses of 20 and $30 \mu \mathrm{g} \cdot \mathrm{mL}^{-1}$ and the time of 2 hours, the cytotoxic effect on the EAT cells was more intense resulting in inactivation of virtually all cells.

\section{Discussion}

The goal of cancer treatment is to eradicate it and the main ways to stop it can be classified into three categories: surgery, radiotherapy and chemotherapy. The chemotherapy aims to destroy the neoplastic cells preserving the normal ones, which is not observed in the majority of chemotherapy that work on a non-selective way, eliminating both neoplastic and normal cells, especially the fast-growing ones. This explains the side effects of chemotherapy: nausea, loss of hair and increased susceptibility to infections ${ }^{8}$.

The hypothesis of the use of cyanogenic substances in the treatment of cancer is anchored by the inefficiency of these cells to eliminate the cyanide due to the reduction of sulfanesulfur compounds -. The regression of tumors transplanted in mice and the inhibition of tumor-induced cancer through the use of different sulfane-sulfur precursors confirm the hypothesis, providing thus in the cancer cells, a perfect environment for poisoning by cyanide due to the cumulative effect of rhodanese be only residual ${ }^{9}$.
The ability of cyanide to penetrate the cell without the action of a receiver is due to the fact that the cyanide ion is a small molecule and its detoxification in mammals occurs mostly mediated by the enzyme rhodanese ${ }^{10}$. This ability was demonstrated in the literature where the cyanide was applied or released by the system Linamarin/Linamarase directly into a solid tumor causing a regression of the same course. Histological analysis of extracted tumor tissue showed large lesions around the site of injection ${ }^{11}$.

The literature demonstrates the efficiency of the use of cyanide in the treatment of cancer through gene therapy, using Linamarin as a source of cyanide ${ }^{12}$, whereas in this study was used a variant on the direct use of Acetone Cyanohydrin (metabolite of Linamarin) for release of cyanide without the need for the use of gene therapy in the process, achieving similar results.

The use of acetone cyanohydrin that spontaneously releases cyanide when in basic $\mathrm{pH}$, released cyanide outside the cell, which was spread through the cell membrane causing cell death, thereby obtaining results similar to that in the literature ${ }^{13}$, without, however, the need to use gene therapy in the process.

The comparison of the effect of Acetone Cyanohydrin in normal cells was satisfactory, showing greater cytotoxic capacity occurring on the Ehrlich Ascites tumor cells as also described in other studies using cyanoglucosides ${ }^{14,15}$, demonstrating absence of intoxication and of inviability of normal cells.

The effect of Acetone Cyanohydrin when in lower doses, demonstrates ability to cumulative poisoning in tumor cells, since the cell survival rate is decreasing with increasing time of exposure to cyanide, which is not observed in tests with human lymphocytes where cell viability was less intense, possibly due to reduced activity of rhodanese is more evident in tumor cells?.

The results are encouraging for the use of Acetone Cyanohydrin in the fight against cancer, but will require further research, especially in animal models (in vivo) to establish a correlation with the results presented here. 


\section{Conclusions}

The research on the conditions it was made helps on the assumption that it is possible to evaluate the effect of cyanide on tumor cells using a different type of liberation than that being reported in the literature, satisfactorily demonstrating the cytotoxic effect of acetone cyanohydrin on Eherlich ascites tumor cells.

The use of Acetone Cyanohydrin caused the death of the Ehrlich ascites tumor cells of 84.9 and $100 \%$ at doses of 20.0 and $30.0 \mu \mathrm{g} . \mathrm{mL}^{-1}$ respectively, in only 2 hours of incubation.

At low concentrations of $0.5,1.0$ and $2.0 \mu \mathrm{g} . \mathrm{mL}^{-1}$, more then $90 \%$ of cell death was observed only after 24 hours of incubation which is the evidence that the tumor cell has the ability to poison cumulatively and irreversibly itself with the cyanide released by acetone cyanohydrin when compared with the results presented by human lymphocytes that the same doses and at the same time of incubation reached a maximum of $30 \%$ of cell death, suggesting an activity of rhodanese differentiated between the two cells.

\section{References}

1. Essers SAJA, Bosveld M, Grift RMVD, Voragen AGJ. Studies on the quantification of epecific cyanogens in cassava products and introduction of a new chromogen. J Sci Food Agric. 1993;63:287-96.

2. Cetesb. Companhia de Tecnologia de Saneamento Ambiental. Ficha de informação de produto químico. Available in: http://www.cetesb.sp.gov.br/ emergencia/produtos/ficha completal.asp?consulta=ACETONA\%20CIANIDRINA. Accessed 10 May 2009

3. Mintel R, Westley J. The Rhodanese reaction: mechanism of sulfur-sulfur bond cleavage. J Biol Chem. 1966;241(14):3381-5.

4. Aminlari M, Malekhusseini A, Akrami F, Ebrahimnejad H. Cyanide-metabolizing enzyme rhodanese in human tissues: comparison with domestic animals. Comp Clin Pathol. 2007;16:47-51.

5. Jamshidzadeh A, Aminlari M, Rasekh HR. Rhodanese and Arginase activity in normal and cancerous tissues of human breast, esophagus, stomach and lung. Arch Iran Med. 2001;4:88-92.

6. Silva RJ Da, Silva MG, Vilela LC, Fecchio D. Antitumor effect of Bothrops jararaca venom. Mediators Inflamm. 2002;11:9-104.
7. Silva TMA, Aoyama H, Haun M, Ferreira CV. Citotoxicidade do promotor de tumor e sua ação mitogênica sobre os linfócitos humanos. RBAC. 2004;34(4):237-9.

8. Ameida VL, Leitão A, Reina LCB, Montanari CA, Donnici CL, Lopes MTP. Câncer e Agentes Antineoplásicos Ciclo-Celular específicos e Ciclo-Celular não específicos que interagem com o DNA: uma introdução. Quim Nova. 2005;28:118-29.

9. Iciek M, Wlodek L. Biosynthesis and biological properties of compounds containing highly reactive, reduce sulfane súlfur. Pol J Pharmacol. 2001;53:215-25.

10. Idibie CA, Davids H, Iyuke SE. Cytotocity of purified cassava linamarin to a selected câncer cell lines. Bioprocess Biosyst Eng. 2007;30:261-9.

11. Link N, Aubel C, Kelm JM, Marty RR, Greber D, Djonov V, Bourhis J, Weber W, Fussenegger M. Theapeutic protein transduction of mammalian cells and mice by nucleic acid-free lentiviral nanoparticles. Nucleic Acids Res. 2006;34(2):e16.

12. Cortés ML, Felipe P, Martín V, Hughes MA, Izquierdo M. Successful use of a plant gene in the treatment of cancer in vivo. Gene Ther. 1998;5:1499-507.

13. Cortés ML, Escudero VG, Hughes MA, Izquierdo M. Cyanide bystander effect of the linamarase/linamarin killer-suicide gene therapy system. J Gene Med. 2002;4:407-14.

14. Kousparou CA, Epenetos AA, Deonarain MP. Antibody-guid enzyme of cancer producing cyanide result in necrosis of targed cells. Int J Cancer. 2002;99:138-48.

15. Newmark J, Brady RO, Grimley PM, Gal AE, Waller SG, Thistlethwaite R. Amygdalin (Laetrile) and prumasin B-glucosidases: Distribution in germ-free rat and in human tumor tissue. Proc Natl Acad Sci USA. 1981;78(10):6513-6.

\section{Acknowledgments}

Dr. Denise Fecchio for her support and collaboration in training techniques for evaluation of tumor growth. Dr. Lízia C. Vilela for her guidance and assistance in implementing the experimental part. Dr. Susana Moreno for providing her lab making it possible to complete the experiment.

Conflict of interest: none

Financial source: none

\section{Correspondence:}

Rondon Tosta Ramalho

Rua Talles, 178

79041-560 Campo Grande - MS Brazil

rondontosta@brturbo.com.br

Received: August 18, 2009

Review: October 20, 2009

Accepted: November 19, 2009

\section{How to cite this article}

Ramalho RT, Aydos RD, Cereda MP. Evaluation of acetone cyanohydrin effect in "in vitro" inativation of the Ehrlich ascites tumor cells. Acta Cir Bras. [serial on the Internet], 2010 Jan-Feb; 25(1). Available from URL: http://www.scielo.br/acb 